\title{
Comunicação, educação e tecnologia: interação
}

Maria Aparecida Baccega

Livre-docente aposentada da USP. Professora de pós-graduação da USP e da ESPM.

Editora da revista Comunicação \& Educação.

E-mail: mabga@usp.br

Este é o primeiro número do décimo ano da revista Comunicação \& Educação, a qual, durante os nove anos anteriores, publicou, regularmente, a cada quatro meses, um novo número. Durante esse período, tivemos as parcerias da Editora Moderna, até o n. 15; da Segmento, até o n. 22, e da Salesiana, até o n. 27. Do final de 2003 e durante todo o ano de 2004, a revista não pôde ser publicada. Volta, agora, em parceria com Paulinas Editora, com grande entusiasmo de ambas as partes: Paulinas e USP. Neste primeiro número, queremos ratificar os compromissos que assumimos desde o início: dialogar com o público sobre esse espaço já construído, onde educação e comunicação se encontram. Trata-se de um espaço cuja ação está presente em cada sala de aula, em cada grupo de pessoas, em cada um de nós. Enfim, vivemos todos imersos num ecossistema comunicativo, no qual se constrói nossa identidade.

E por que podemos afirmar que Comunicação \& Educação é um espaço já construído? Como diz Paulo Freire, nós vivemos no mundo e com o mundo. E que mundo é esse? É aquele que é trazido até o horizonte de nossa percepção, até o universo do nosso conhecimento.

Afinal, não podemos ver todos os acontecimentos, em todos os lugares. É preciso que "alguém" os relate para nós. O mundo que nos é trazido, que conhecemos e a partir do qual refletimos é um mundo que nos chega editado, ou seja, ele é redesenhado num trajeto que passa por centenas, às vezes milhares de filtros até que "apareça" no rádio, na televisão, no jornal. Ou na fala do vizinho, nas conversas dos alunos, nos diálogos do cotidiano. São esses filtros - instituições e pessoas - que selecionam o que vamos ouvir, ver ou ler; que fazem a montagem do mundo que conhecemos.

Aqui está um dos pontos básicos da reflexão sobre o espaço onde se encontram comunicação e educação e que gostaríamos de mostrar: que o mundo é editado e assim ele chega a todos nós; que sua edição obedece a interesses de diferentes tipos, sobretudo econômicos, e que, desse modo, acabamos por perceber até a nossa própria realidade do jeito que ela foi editada. 
Portanto, editar é construir uma realidade outra, a partir de supressões ou acréscimos em um acontecimento. Ou, muitas vezes, apenas pelo destaque de uma parte do fato em detrimento de outra.

Editar é reconfigurar alguma coisa, dando-lhe um novo significado, atendendo a determinado interesse, buscando um determinado objetivo, fazendo valer um determinado ponto de vista.

É o que Entman, citado por Lima, chama de enquadramento: "A noção de enquadramento envolve basicamente seleção e saliência, sendo que esta última consiste em tornar uma informação mais 'noticiável, significativa ou memorável para a audiência'. Desta forma, 'enquadrar é selecionar certos aspectos da realidade percebida e torná-los mais salientes no texto da comunicação de tal forma a promover a definição particular de um problema, de uma interpretação causal, de uma avaliação moral e/ou recomendação de tratamento para o tema descrito. Enquadramentos, tipicamente, diagnosticam, avaliam e prescrevem'. Além disso, 'o enquadramento determina se a maioria das pessoas percebe e como elas compreendem e lembram-se de um problema, da mesma forma que determina a maneira que avaliam e escolhem a forma de agir sobre ele""1.

Até agora só falamos de um lado: o da produção do programa (de rádio ou televisão), jornais, revistas etc., o lado que edita o mundo. Mas há o outro lado: o daqueles a quem esses produtos culturais se dirigem. O outro lado somos nós, os alvos de toda essa produção. Somos um lado também muito importante, porque não somos passivos, não somos meros recipientes onde os produtos da chamada indústria cultural são despejados e inteiramente absorvidos. A comunicação só acontece no encontro desses dois lados: emissor (enunciador) e receptor (enunciatário). Os programas só acontecem quando nós os vemos e ouvimos; os jornais e revistas, quando os lemos. A comunicação só se efetiva quando o enunciado é apropriado por quem recebe, por nós. Só então se constroem os significados. O significado não reside no que diz o emissor; também não se constrói apenas com a percepção do receptor. Os significados se instituem no território que se forma no encontro emissor/receptor. E são esses significados que regem o nosso cotidiano. Os meios de comunicação, incluídos os novíssimos - internet, por exemplo -, têm grande responsabilidade na construção e disseminação desses significados. Daí a importância de seu conhecimento. Assim, procuramos desvendar os mecanismos usados na sua edição, conseguindo percorrer o trajeto que vai do mundo que nos entregam pronto, editado, à construção do mundo que permite a todos o pleno exercício da cidadania.

1. ENTMAN, Robert. Framing: toward clarification of a fractured paradigm. Journal of Communication, vol. 43, n. 4, Autumn, pp. 51-58, Apud LIMA, Venício A. Duas questões de comunicação pública, $p$. 4. Mimeo.

\section{TECNOLOGIA E ESCOLA}

No século XV, as caravelas portuguesas, depois de muitos dias e noites, aportaram aqui. Pero Vaz de Caminha, o "repórter" de confiança da Coroa portuguesa, mandou a notícia. Ele escreveu: "Esta terra, senhor, (...) em tal maneira é graciosa que, querendo-a aproveitar, dar-se-á nela tudo; por causa das águas que tem". 
Essa notícia chegou imediatamente a Portugal. Meses depois. Esse era o tempo do "imediatamente" que a tecnologia da época permitia.

Hoje, assistimos a guerras, assassinatos, festas, muitas vezes no mesmo momento em que ocorrem. É o "imediatamente" de hoje. A diferença de tempo entre o acontecimento e a divulgação das notícias se deve ao avanço da tecnologia: é ela que reduz o tempo e encurta as distâncias. Os pontos mais longínquos do planeta são trazidos para a sala de nossa casa. Este é o novo mundo.

Hoje, provavelmente, Caminha mandaria um e-mail para a Coroa e a correspondência secreta iria por jato, caso não fosse escaneada, seguindo também pela internet.

Os avanços tecnológicos compõem a nova realidade. A cada conquista, há uma reconfiguração do anteriormente conquistado. Nenhum deles desaparece: fotografia, cinema, televisão, computador.

Essas mudanças estão aí, não há como escapar. Com um telefone e um computador, temos acesso ao mundo em segundos. Dessa vez, há os que dizem que a escola acabou. O professor foi substituído pelo computador, pelo vídeo e pela televisão. Será?

O contato diário com tantas outras culturas, resultado das novas tecnologias, implica uma rápida e permanente atualização da nossa cultura: instaura-se uma reconfiguração das instituições e uma discussão de valores. Permite, desse modo, que consolidemos nossos valores, ratificando-os ou reformulando-os. Permanecerão nas nossas culturas aqueles traços que todos decidirmos como marcas da diferença, as quais nos distinguirão no conjunto das culturas, na inter-relação com elas. São os traços que mostram nossos jeitos de ser e de viver e fazem que todos nos sintamos participantes do mesmo universo, da mesma nação. E, a partir desses traços, seremos identificados e respeitados.

Assim vai se dando, com a rapidez que a tecnologia permite, o processo de construção/reconstrução de identidades, inseridas todas na internacionalização do mundo, ao mesmo tempo que se reforçam, pelas marcas da diferença, as culturas locais e regionais.

Essa mudança no perfil da sociedade atinge a escola, exigindo que ela se dedique, cada vez mais, a seu objetivo maior: a formação de cidadãos críticos. Logo, essas mudanças consolidam a instituição escolar e sobrelevam o papel do professor.

As ofertas dos produtos que podemos ler, ouvir e ver aumentam a cada dia. Entre tantos, podemos citar a televisão a cabo, que nos permite ter acesso a programas de várias partes do mundo, no momento em que estão acontecendo, e a internet, que possibilita a interação em tempo real. Mas o nosso dia continua a ter 24 horas.

É preciso, portanto, que se saiba, primeiro, escolher o que queremos ver, ouvir ou ler; segundo, que saibamos "ler" esses produtos, inter-relacionando-os entre si e relacionando-os com o que acontece ao nosso redor; terceiro, que essa inter-relação seja resultado da consolidação de objetivos que reflitam a nossa cultura e a construção de um mundo mais humano.

Para que isso ocorra, é fundamental garantir o espaço de reflexão. E o espaço privilegiado de reflexão é sempre, e continuará sendo, a escola. A coordenação do processo estará sempre nas mãos do professor. 
Sabemos que a tecnologia está na escola. Não exatamente na forma de aparelhos sofisticados (ainda são tão poucas as que os possuem, disponíveis para todos), mas sim na cultura dos alunos que nela estão. Eles são resultado desse mundo pleno de tecnologias, dessa nova cultura, independentemente do nível socioeconômico a que pertencem. Por isso, no campo da educação, o desafio maior tem sido a busca da incorporação dessa tecnologia na dimensão sociocultural.

Nessa reconfiguração e redimensionamento da escola, um dos eixos é ensinar o aluno a trabalhar a informação, dando-lhe condições de incorporá-la a partir do conjunto de idéias, valores e objetivos da cultura, tornando-a conhecimento e utilizando-a para colaborar na solução dos problemas de sua realidade.

É necessário, sem dúvida, que os aparelhos tecnológicos estejam à disposição das escolas. Porém, o que estamos querendo mostrar é que, mais importante que isso, é fundamental que sejam dadas ao professor condições para ser o grande condutor nos caminhos desse mundo de realidades virtuais e de realidades vividas e construídas.

Só a escola poderá formar cidadãos que usem a tecnologia para diminuir a distância entre o homem-cidadão e o homem desrespeitado na sua condição humana.

O uso do computador, por exemplo, tem se revelado de grande valia no ensino. Porém, se o uso do computador ocorre apenas na perspectiva de instrução, seu valor ficará dramaticamente reduzido. A educação continuará a ter como base a reprodução do conhecimento e o computador servirá apenas para colocar à disposição do aluno, descritivamente, uma gama maior de informação acumulada no decorrer dos séculos.

O computador, o vídeo, o DVD ou outros aparelhos têm de ser vistos como presenças na realidade contemporânea na qual nós, alunos e professores, estamos imersos. Portanto, como presenças no processo de educação. Serão usados pelo professor conforme seus objetivos, a partir do planejamento que elaborou, com vistas a objetivar o acesso crítico ao conhecimento. Por isso, podemos afirmar, sem cometer exagero: o papel primeiro da escola - de ensinar com criticidade - é retomado de maneira definitiva nesses novos tempos de tecnologias. À escola compete educar, ou seja, fazer com que o aluno aprenda a aprender.

A tecnologia obriga a escola a ser o que sempre objetivou: crítica, fazendo do aluno não um vaso recipiente de conhecimentos prontos - passivo, portanto -, mas um ser ativo, um sujeito da história. Com a ajuda da tecnologia.

Este número de Comunicação \& Educação trata de algumas experiências e reflexões que trazem a tecnologia contemporânea como base.

\section{ARTIGOS NACIONAIS}

Jogos na web e ensino da história da arte, de Tania Callegaro, é o artigo que abre tais reflexões, ao tratar da temática das relações da arte com a internet. Discussão que se revela fundamental, pois está na base, entre outros aspectos, das questões pertinentes ao novo sensorium dos jovens. Segundo a autora, "as propostas contemporâneas que buscam a experiência artística por meio do jogo 
exploram a linguagem multimídia e hipertextual das tecnologias digitais e da internet”, pois "o jogo é estrutura e proposta das poéticas da experimentação, que permite, com maior ou menor grau de interatividade, um contato, uma participação que leva a uma mudança contínua no contexto em que se joga e nas formas resultantes". Para que as novas formas revelem os novos conteúdos que trazem, será sempre indispensável a presença do professor, no caso um arte-educador.

Beatriz Schmidt, em Interação e práticas sociais, apresenta-nos o conceito de coprodução que a autora revela como o mais apropriado para o pólo da recepção. Segundo ela, "por estarmos lidando com campos diferentes - produção e coprodução - a perspectiva interacional deve ser vista como um processo de relação, de articulação, de negociação, em que os sujeitos atuam com suas experiências e poderes intrínsecos de forma fundamentalmente criativa”. Ou seja: como dissemos, a instituição de significados ocorre no território que se constrói entre os dois pólos: produção e co-produção, tradicionalmente chamados de emissão e recepção. Esse enfoque percorre, em conjunção, os campos comunicação e educação.

Se nos pedissem para descrever qual a imagem de cientista que temos, o que responderíamos? É sobre isso que escreve Lacy Barca, em As múltiplas imagens do cientista no cinema, em que a autora discorre sobre os filmes que foram responsáveis por essas imagens, a partir de 1902. Importante para que percebamos o quanto nosso imaginário foi e é formado pelas imagens audiovisuais divulgadas pela mídia.

"O produto que melhor representa as potencialidades das Novas Tecnologias de Informação e Comunicação (NTIC) é a internet.” Assim Cibele Abdo Rodella inicia seu artigo Internet: um novo paradigma de informação e comunicação. Apontando o internauta como o paradigma do cidadão global, a autora lembra que a internet e a sociedade mantêm uma relação dialética de modificação de ambos os lados, graças à interatividade e ao novo conceito de tempo/espaço aí construídos.Destaca também a necessidade da vigilância para que o uso democrático das NTIC seja preservado.

\section{ARTIGO INTERNACIONAL}

A comunicação como conhecimento é a contribuição de Cristina Baccin, pesquisadora argentina. A partir dos acontecimentos ocorridos na Argentina, em dezembro de 2001, que resultam do período em que a qualidade de vida do povo decresceu significativamente e em que os acordos institucionalizados foram rompidos, em função da política do FMI, a autora apresenta suas reflexões sobre o compartilhamento do conhecimento para a resolução dos problemas. Tais reflexões incluem os campos da comunicação e da educação.

\section{ENTREVISTA}

João Antonio Zuffo é o entrevistado deste número. Em A infoera transformando as relações sociais, entrevista concedida a Izabel Leão, o professor e pesquisador da Escola Politécnica da USP nos alerta: "A infoera é a era da informação que está mudando os valores da sociedade e o relacionamento humano. Eu diria 
que é a mudança mais profunda ocorrida na história da humanidade”. Ele trata das relações familiares e da escola nessa nova realidade. Diz: "O ensino vai ter de deixar de ser estanque e, mais ainda, precisaremos de um ensino básico muito mais sólido, pois é o único que fica. No resto, haverá um vendaval de mudanças", pois "a formação tende a ser mais humanista" e "a área de humanas é a que menos sofrerá a concorrência das máquinas, dos computadores”.

Além disso, o entrevistado fala da internet, do ensino a distância e lembra que "a criatividade vai ser fundamental. Tudo indica que as profissões puramente técnicas irão desaparecer. As atividades voltadas para o bem-estar pessoal terão grande desenvolvimento".

\section{CRÍTICA}

Adílson Citelli, em Estratégias de resistência à mídia hegemônica, faz a crítica do livro de Downing et al., Mídia radical. Rebeldia nas comunicações e movimentos sociais, lançado pela Editora Senac.

Os autores "elaboram um vasto estudo dos movimentos de rebeldia em diferentes partes do mundo e buscam, pela comunicação, saídas democráticas, de ampliação da participação popular: as rádios e televisões comunitárias; a imprensa alternativa, o acesso e livre circulação das informações através da internet; as estratégias de resistência contra regimes fechados e/ou ditatoriais”.

\section{DEPOIMENTO}

A radialista Cristina Coghi concordou em dar seu depoimento sobre o "outro lado" de um programa de rádio. O resultado é o comovente relato de treze reportagens feitas pela autora para a Rádio CBN, de São Paulo, sobre a Casa de Detenção de São Paulo, tendo como gancho sua desativação. "Como é diferente registrar um fato e de fato enxergar a notícia”, diz Cristina.

\section{EXPERIÊNCIA}

Câmera e vídeo na escola: quem conta o que sobre quem?, de Adriana Maricato de Souza, fala-nos da importância do uso do vídeo. "Num espaço em que primeiro o diretor e depois os professores são donos das vozes, a narrativa audiovisual tem o potencial de gerar diálogo dentro da escola e com a comunidade do entorno." Este trabalho de alfabetização audiovisual foi levado a efeito pela autora na zona leste de São Paulo, por meio de oficinas de vídeo com alunos e professores de escolas municipais.

\section{POESIA}

Carlos Drummond de Andrade, eterno poeta maior, está neste número. Pela atualidade de seus poemas, escolhemos três deles que dizem muito diretamente da realidade contemporânea: Menino chorando na noite, Os ombros suportam o mundo e Mãos dadas. 


\section{SERVIÇOS}

Ismar de Oliveira Soares, em NCE - A trajetória de um núcleo de pesquisa da USP, faz um breve histórico do Núcleo de Comunicação e Educação, criado em 1986, que tem realizado pesquisa-ação e conta com variados serviços prestados ao campo comunicação/educação, entre eles: educom.rádio, educom.tv, todeolho.tv, educom.mídia.

\section{VIDEOGRAFIA}

História e literatura através do cinema, de Maria Ignês Carlos Magno, compõe a seção Videografia. Preocupada com o fato de que tais campos de conhecimento, indispensáveis à formação dos alunos, nem sempre chegam a eles de maneira adequada, a autora propõe uma aproximação através de filmes. Foram escolhidos Como era gostoso o meu francês, Memórias do cárcere e Anchieta José do Brasil, os quais são analisados com esse objetivo.

\section{BOLETIM BIBLIOGRÁFICO}

Bibliografia sobre telenovela brasileira, assinado por Anamaria Fadul, resenha as últimas contribuições de estudiosos sobre essa temática tão presente na realidade brasileira, a ponto de pautar as discussões do cotidiano; Bibliografia sobre comunicação e educação, assinado por Ismar de Oliveira Soares, destaca algumas das últimas contribuições editoriais ao campo, e Enderȩ̧os úteis na internet, produção de Patrícia Carla dos Santos, apresenta alguns endereços que certamente serão de muita importância no desenvolvimento de reflexões e de projetos educacionais.

\section{ATIVIDADES EM SALA DE AULA}

Ruth Ribas Itacarambi sugere duas atividades com os textos deste número, a serem desenvolvidas em sala de aula: a primeira, Ciência, sociedade e mídias, tem como base a entrevista de Zuffo e os artigos de Barca e Schmidt; a segunda, Emissão e recepção nas NTIC, baseia-se sobretudo nos artigos de Rodella e Callegaro. São atividades que muito interessarão aos alunos. 
Resumo: $O$ artigo reapresenta os compromissos da revista, sua proposta editorial, que se funda nos avanços do campo comunicação/educação. Destaca que a publicação colabora para a formação do leitor crítico, proporcionando-lhe condições para a compreensão dos mecanismos utilizados pelos meios de comunicação para a edição ou enquadramento do mundo. Reflete sobre as interações comunicação, educação, tecnologia, destacando a necessidade de reconfiguração e redimensionamento da escola nessa realidade.
Abstract: This article reintroduces this journal engagements, its editorial proposes, founded on the developments of the communication/ education field. It highlights this publication's contribution to forming the critical lecturer by offering the lecturers conditions for comprehending media mechanisms to edit or frame the world. It reflects on the interactions of communication, education and technology, highlighting the need for reconfigurating and redimensioning the school in this reality. 